\title{
Yield Stability in Pigeon pea Hybrids [Cajanus cajan (L.) Millsp.] Under Varying Agro-Climatic Regions
}

\author{
Uttam Chand • Ashok Narayan Tikle • Niraj Kumar • \\ Kul Bhushan Saxena • Sunil Chaudhari
}

received: 11 January 2014, accepted: 24 February 2014

published online: 2 June 2014

(C) 2014 IFVC

doi: $10.5937 /$ ratpov51-5326

\begin{abstract}
Summary: Twelve pigeonpea genotypes comprising ten hybrids and two controls were evaluated at three environments during rainy season of 2012-13, to study genotype $\times$ environment interaction for yield and related traits. Analysis of variance in each environment and on a pooled basis expressed a significant difference among genotypes for yield and yield contributing characters except for 100 seed weight. Genotype $\times$ environment (linear) interactions were found significant for days to $50 \%$ flowering, plant height, primary and secondary branches per plant, pods per plant, seeds per pod, grain yield per plant and yield ( $\mathrm{kg} / \mathrm{ha}$ ) except days to maturity and 100 seed weight. The regression and GGE biplot methods were used for analysis. Both methods identified ICPH 2671, ICPH 2740 , ICPH 3933 and ICPH 3762 as stable hybrids. The GGE biplot explained higher proportion of the mean sum of squares of the $\mathrm{G} \times \mathrm{E}$ interaction and was more informative with regards to environments and their genotypic performance than the regression method. Hybrids ICPH 2671, ICPH 2740, ICPH 3762 and ICPH 3933 showed stability for the yield and yield components and could be recommended for cultivation.
\end{abstract}

Key words: Cajanus cajan, GxE interaction, GGE biplot, hybrids, pigeon peas, yield stability

\section{Introduction}

Pigeonpea (Cajanus cajan (L.) Millsp.) is an important pulse crop of the semi-arid tropics of the Indian subcontinent, Africa and Caribbean region. The global production of pigeon pea is 4.32 million tons from an area of $5.32 \mathrm{~m}$ ha with a productivity of $813.2 \mathrm{~kg} / \mathrm{ha}$ (FAO, 2012). India is the largest producer and consumer of pigeon pea with an area of $3.86 \mathrm{~m}$ ha followed by Myanmar $(0.64 \mathrm{~m}$ ha), Malawi (0.19 m ha), Kenya (0.13 m ha) and Uganda $(0.09 \mathrm{~m} \mathrm{ha})$. In pigeon pea, development of a stable cytoplasmic nuclear male-sterility (CMS) system (Saxena et al. 2005, 2010), identification

U. Chand • A.N. Tikle $\bullet$ S. Chaudhari

RAK College of Agriculture, Sehore, 466001, Madhya Pradesh, India e-mail:antiklepb@gmail.com

U. Chand $\bullet$ K.B. Saxena $\bullet$ S. Chaudhari

International Crops Research Institute for the Semi-Arid Tropics, $\mathrm{Pa}$ tancheru, 502324, Andhra Pradesh, India

e-mail: u.chand@cgiar.org

N. Kumar

Birsa Agricultural University, Ranchi, 834004, Jharkhand, India of fertility restorer (Saxena et al. 2011, and Dalvi et al. 2008) by exploiting partial natural outcrossing (Saxena \& Sharma 1990) and existence of significant standard heterosis (Kyu et al. 2011) have opened a new research avenue for enhancing yield through hybrid breeding. This CMS system has been reported to be highly stable in diverse environments (Dalvi et al. 2010, Sawargaonkar et al. 2011). Genotype and its interaction with prevailing environment is the crucial factor, which determine the final yield. Stability of performance across diverse environments and high productivity are most desirable attributes of a crop variety (Wanjari et al. 1988). It is necessary to screen and identify phenotypically stable genotype for yield which could be more or less uniform under different environments. In pigeon pea it can be emphasized that $\mathrm{G} \times \mathrm{E}$ interaction underlines the very success of scientific crop improvement

\footnotetext{
Acknowledgements:

The authors acknowledge Bill and Melinda Gates Foundation (through Tropical Legume II project) for providing financial support to the first author as M.Sc. student.
} 
programme related to stability of genotypes. In the regression method, data were subjected to the combined analysis of variance followed by the procedure outlined by Eberhart \& Russel (1966). The second analysis was genotype main effects and genotype $\times$ environment interaction (GGE) methodology, which is composed of two concepts, the biplot concept (Gabriel 1971) and GGE concept (Gauch \& Zobel 1996, Yan et al. 2000). The present study was aimed at understanding the $\mathrm{G} \times \mathrm{E}$ interaction of pigeon pea hybrids and varieties over the geographical locations for yield and yield attributes.

\section{Materials and Methods}

The materials used in present study comprised 12 pigeon pea genotypes (ICPH 3933, ICPH 2671, ICPH 2740, ICH 3477, ICPH 4490, ICPH 3494, ICPH 2751, ICPH 3491, ICPH 3762, ICPH 3461 and two varietal controls Maruti and Asha) developed at the International Crops Research Institute for Semi-Arid Tropics (ICRISAT), Patancheru (Andhra Pradesh). Ten medium duration hybrids, developed by crossing five CMS lines (ICPA 2043, ICPA 2047, ICPA 2048, ICPA 2078 and ICPA 2092) containing $\mathrm{A}_{4}$ cytoplasm (Saxena et al., 2005) and six different fertility restorer (ICPL 87119, ICPL 20093, ICPL 20096, ICPL 20098, ICPL 20108 and ICPL 20126) were evaluated under three environments. The trials were conducted during the rainy season of 2012-2013, using randomized complete block design (RCBD) with two replications. The genotypes were planted at three different locations - Patancheru, Andhra Pradesh $\left(17^{\circ} 53^{\prime} \mathrm{N}, 78^{\circ} 27^{\prime} \mathrm{E}\right.$ and $\left.545.0 \mathrm{~m}\right)$, Ranchi, Jharkhand $\left(23^{\circ} 17^{\prime} \mathrm{N}, 85^{\circ} 19^{\prime} \mathrm{E}\right.$ and $\left.625.0 \mathrm{~m}\right)$ and Sehore, Madhya Pradesh (23 $12^{\prime} \mathrm{N}, 77^{\circ} 05^{\prime}$ $\mathrm{E}$ and $498.7 \mathrm{~m}$ ) of three different sowing dates viz., 29 June 2012, 11 July 2012 and 16 August 2012. Each plot consisted of six rows of 3 meter length. Row to row and plant to plant spacing was kept of $75 \mathrm{~cm}$ and $50 \mathrm{~cm}$, respectively. Data on grain yield and yield contributing characters were recorded from five randomly selected plants in each plot from the middle four rows. The basal fertilizer dose $20 \mathrm{~N}: 60 \mathrm{P}(\mathrm{kg} / \mathrm{ha})$ was applied and recommended package of practices was adopted for an optimum crop growth (Mula et al. 2010). Statistical computations and estimations were carried out using GENSTAT software (version 9.0) mainframe computer system at International Crops Research Institute Semi-Arid Tropics (ICRISAT) Patancheru, Hyderabad (A.P.), India. Each location in a given season was considered as an individual environment. Data obtained from each location was analysed separately by running a single analysis of variance and thereafter data were pooled for analysis of variance to perform the combined analysis of genotypes across locations. Analysis of variance was carried out to partition the variation due to genotypes, environment and genotype by environment interaction. Two analysis procedures were used for the distribution of genotypes in different ecological environments, one suggested by Eberhart \& Russell (1966) and another GGE biplot by Yan et al. (2000). These methods were deployed to investigate the response of the genotypes to environments for days to $50 \%$ flowering, days to $75 \%$ maturity, plant height $(\mathrm{cm})$, number of primary branches/plant, number of secondary branches/plant, number of pods/ plant, number of seeds/pod, grain yield/plant $(\mathrm{g}), 100$ seed weight $(\mathrm{g})$, grain yield/plot $(\mathrm{g})$ and grain yield $(\mathrm{kg} / \mathrm{ha})$. The comparison of the two analytical procedures was made with respect to stability of the test lines.

\section{Results and Discussion}

Phenotypically stable varieties are usually sought for commercial production of crop plants. The present investigation was carried out to collect information on newly developed pigeon pea hybrids and control for their stability in diverse different environments. All 12 pigeon pea genotypes significantly differed from each other indicating thereby substantial variation among the means. Mean performance of genotypes for each of the characters over the three locations is presented in Table 1.1 to 1.3. Overall, the highest grain yield was recorded at Ranchi followed by Patancheru and Sehore. Hybrid ICPH 2671 produced highest grain yield/plant $(72.8 \mathrm{~g})$ followed by ICPH $4490(65.5 \mathrm{~g})$ and ICPH 3461 (65.3 g). All the hybrids were significantly superior compared to the controls Maruti and Asha for grain yield (kg/ ha). ICPH 2740 recorded significantly superior for grain yield $(1674.0 \mathrm{~kg} / \mathrm{ha})$ followed by ICPH $2671(1634.9 \mathrm{~kg} / \mathrm{ha})$ and ICPH $4490(1692.4$ $\mathrm{kg} / \mathrm{ha}$ ). Pooled analysis of variance also revealed significant differences among genotypes for all the traits. The $\mathrm{G} \times \mathrm{E}$ interactions were also significant for all the traits except days to maturity and 100 seed weight $(\mathrm{g})$ which indicated differential response of genotypes to the environments (Table 2). Phad et al. (2005) also found significant $G \times E$ interaction for yield and its related traits of pigeon pea. Mean sum of square due to environment (linear) was significant for all the traits except days to $50 \%$ flowering and 100 seed weight. The 


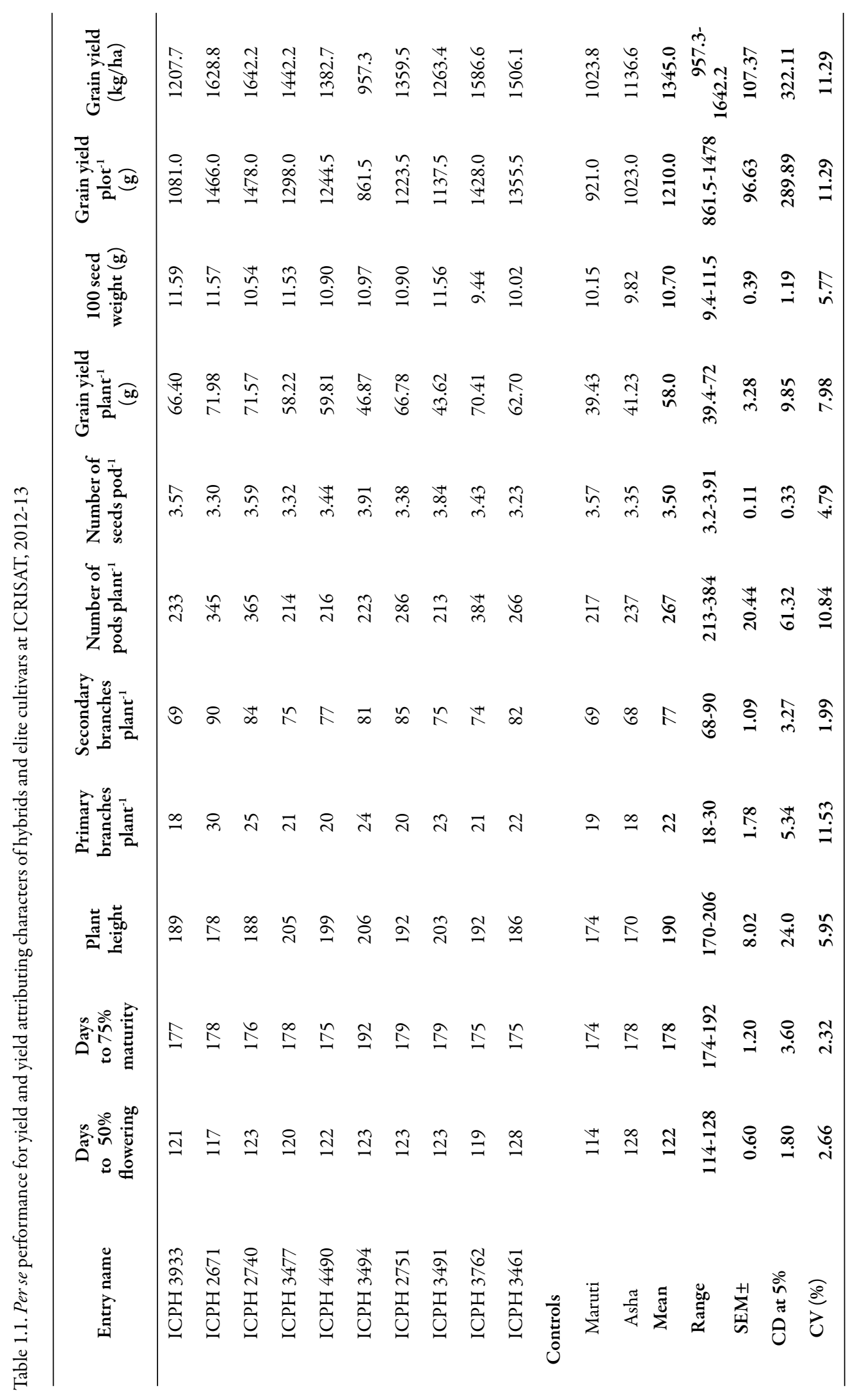




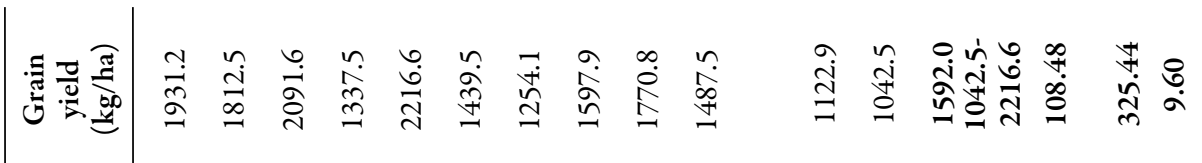

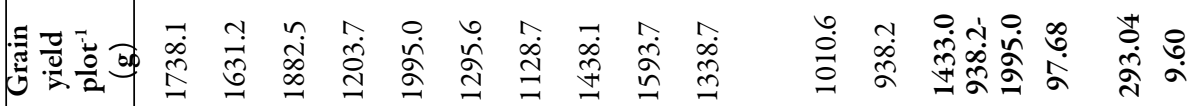

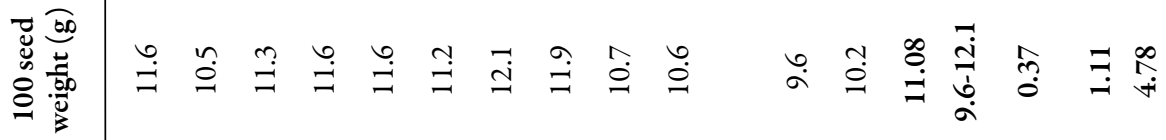

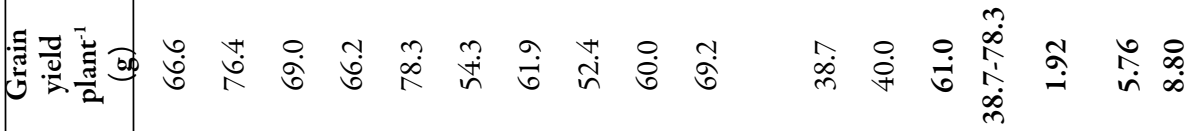

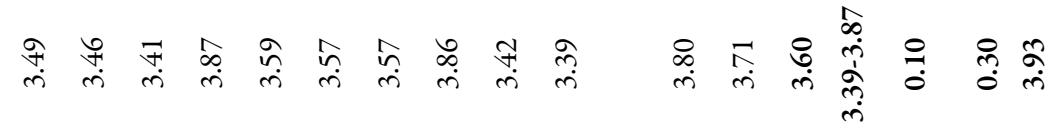

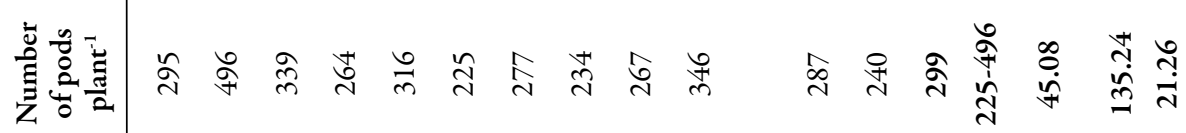

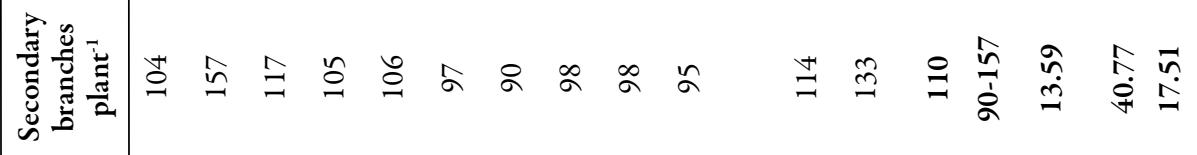

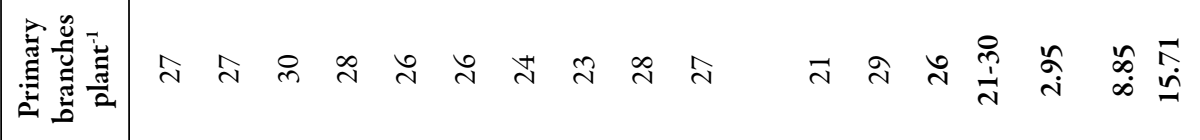

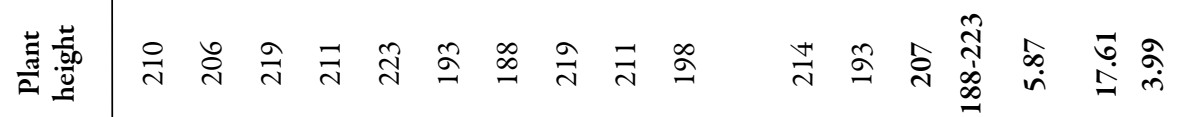

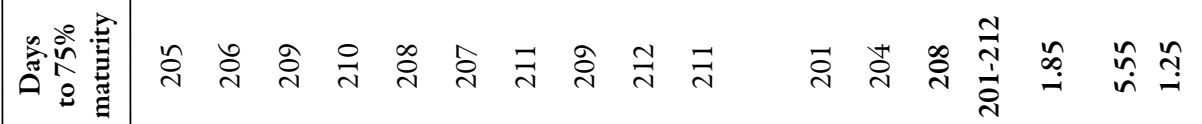

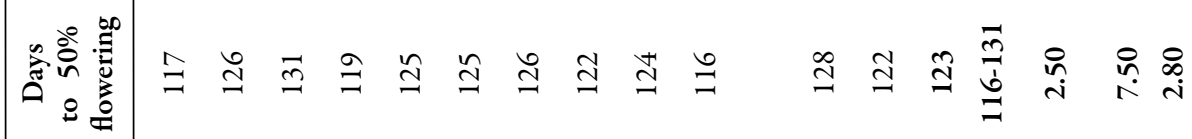
营

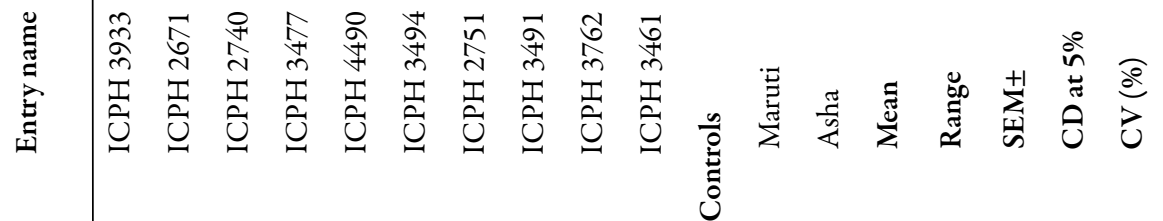




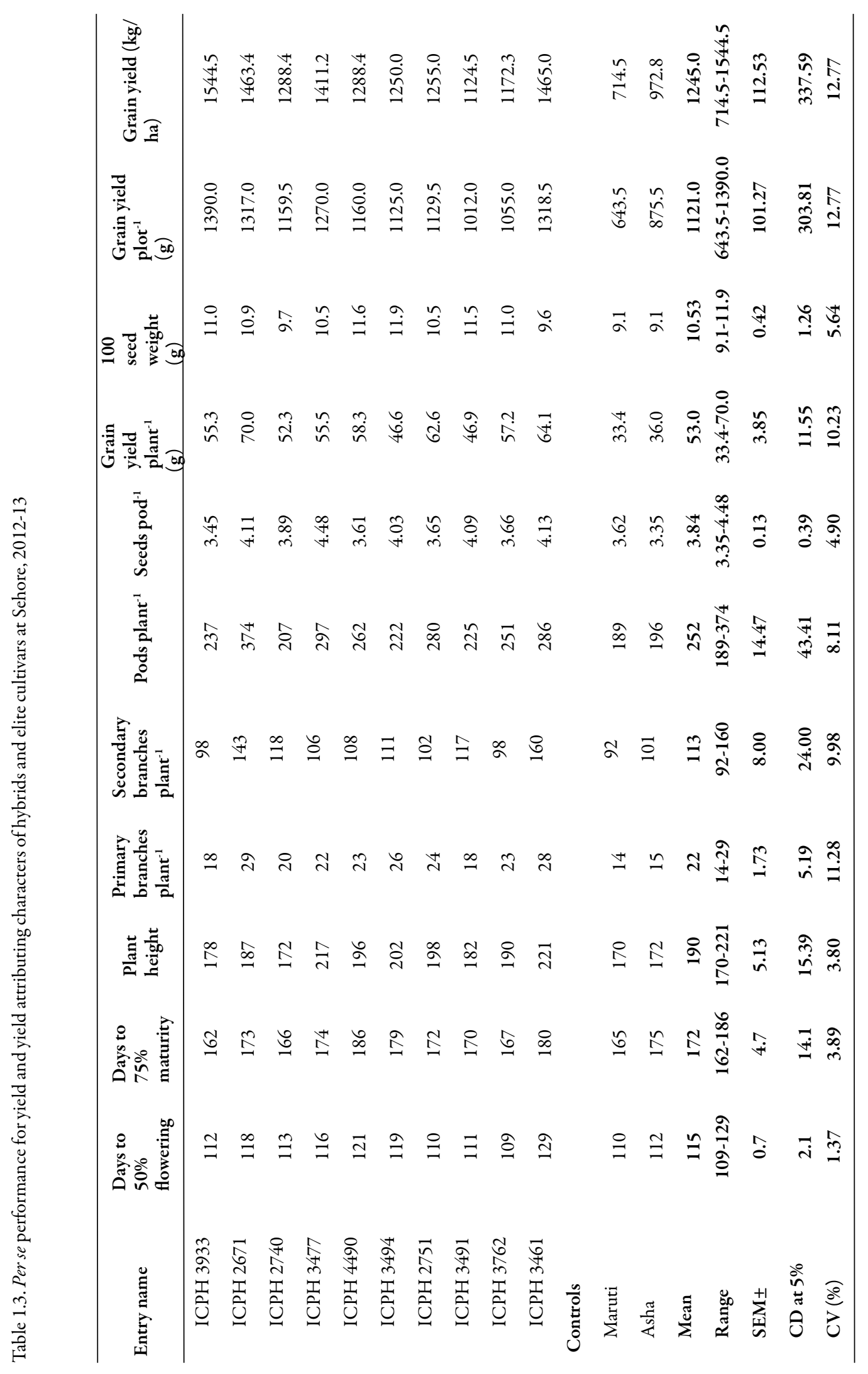




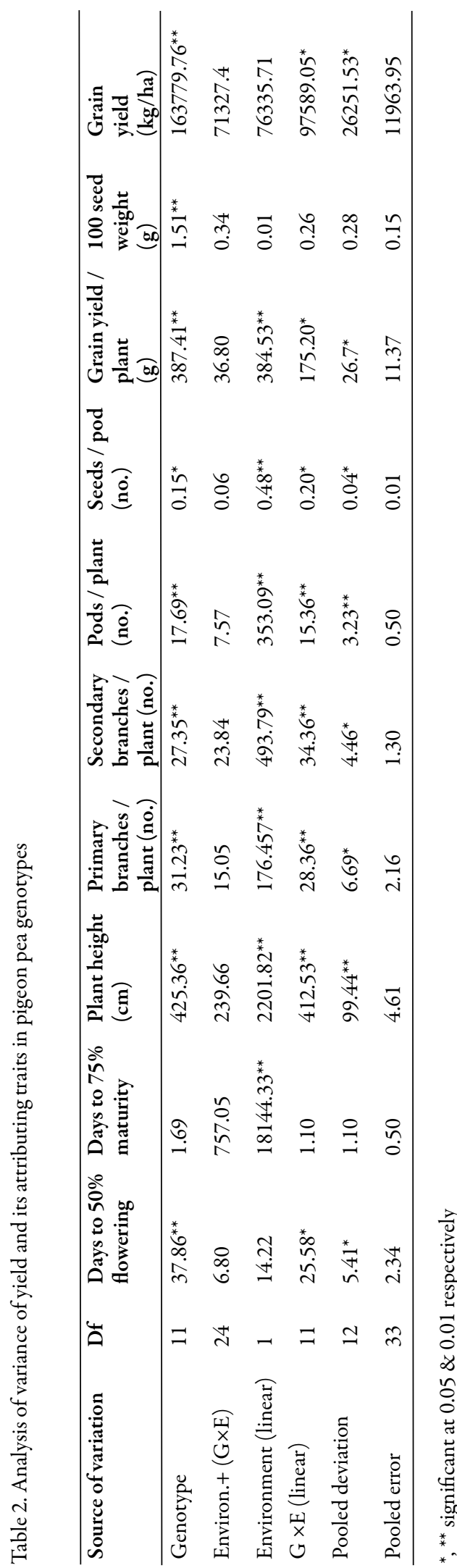

$\mathrm{G} \times \mathrm{E}$ (linear) and pooled deviation (non-linear) components were highly significant for all the traits except days to maturity and 100 seed weight $(\mathrm{g})$, this demonstrated that genotypes respond differently to variation in environmental condition. The seasonal variation in these characters may be due to climatic or soil factor differences among environments during pod formation.

\section{Stability Analysis of Hybrids}

Hybrids ICPH 2671, ICPH 2740, ICPH 2751 and ICPH 3933 with regression coefficients near unity had average stability and were consistent for high grain yield/plant in all the three environments. Three hybrids ICPH 3933, ICPH 2671 and ICPH 3494 were stable for days to $50 \%$ flowering, while most of the genotypes were stable for maturity except ICPH 4490 and ICPH 3494 in different three locations (Table 3a). ICPH 2671 and ICPH 4490 were stable for primary branches/plant and ICPH 2671, ICPH 2740, ICPH 3477, ICPH 4490, ICPH 3494, ICPH 2751, ICPH 3491 and 3762 were found to be stable for number of secondary branches/plant, ICPH 2671, ICPH 2740, ICPH 3461 and ICPH 2751 suitable hybrids for pods/plant (Table $3 \mathrm{~b}$ ). The two hybrids ICPH 2671 and ICPH 2740 had a highest grain yield of $1634.9 \mathrm{~kg} / \mathrm{ha}$ and $1674.0 \mathrm{~kg} / \mathrm{ha}$ respectively, followed by ICPH 4490 having grain yield of $1629.4 \mathrm{~kg} / \mathrm{ha}$ and was also found to be stable among the tested hybrids (Table 3b). Hybrid ICPH 2671 was found stable for most of the yield and its attributing characters except secondary branches/plant. Varied response of genotypes to different environments to yield characters including grain yield/plant was also reported by Ghodke et al. (1992), Manivel et al. (1998), Kalaimagal \& Ravikesavan (2003) and Thanki et al. (2007).

\section{GGE Biplot Method}

GGE ranking biplot of stability and mean performance for grain yield, the GGE biplot method was used for interpreting the result (Fig. 1). In this graph the first two PC's (principal components) explained $89.63 \%$ ( $\mathrm{PCl}=73.85 \%$ and $\mathrm{PC} 2=15.79 \%)$ of the total variation among the data (Fig. 1) Both PC1 (73.85\%) and PC2 (15.79\%) were high for grain yield/plant. Genotype G2 (ICPH 2671) and G3 (ICPH 2740) exhibited highest mean and were stable, while G12 (Asha) and G11 (Maruti) had low mean and unstable. In terms of stability, the GGE Biplot identified G2 (ICPH 2671), G3 (ICPH 2740), G1 (ICPH 


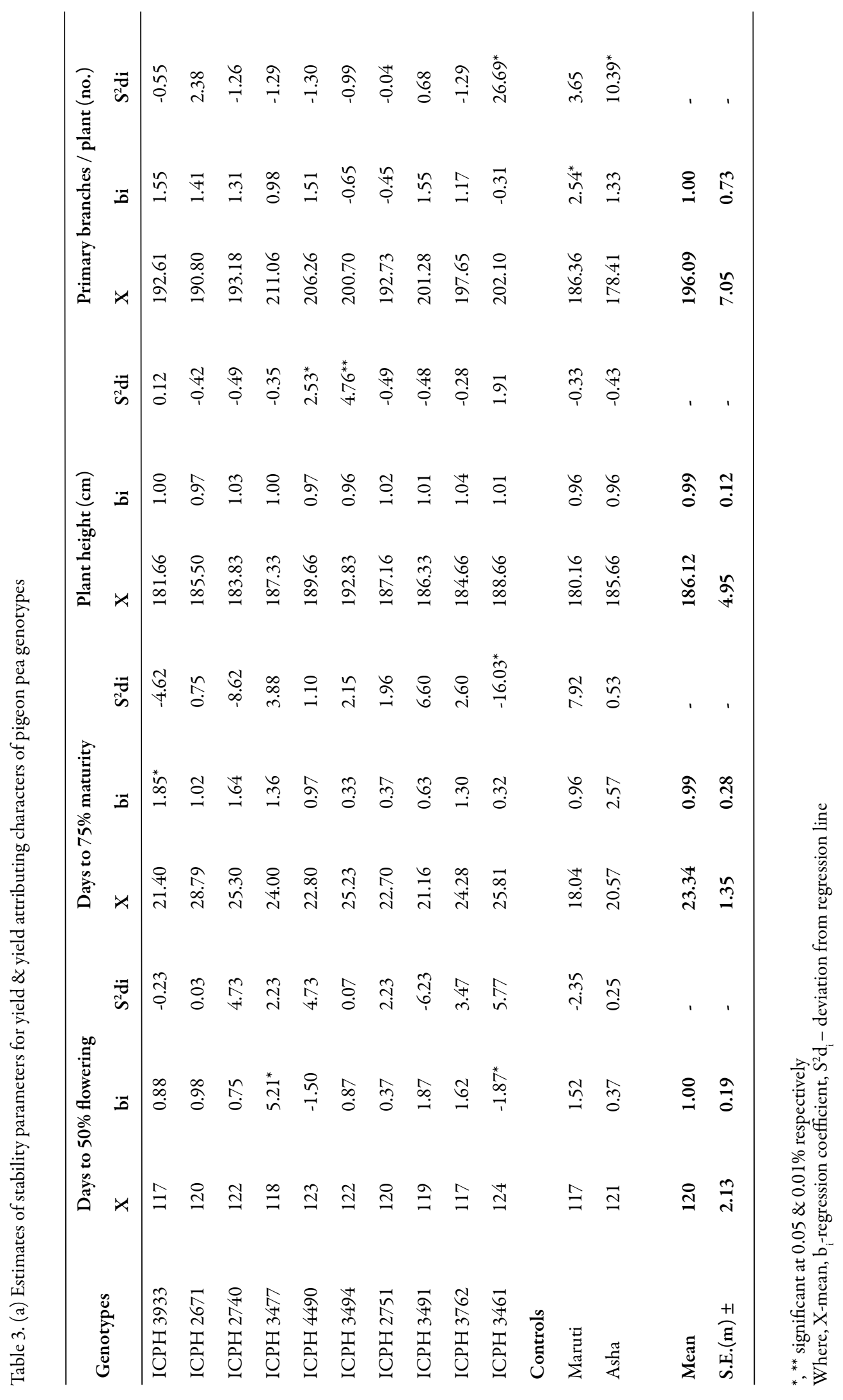




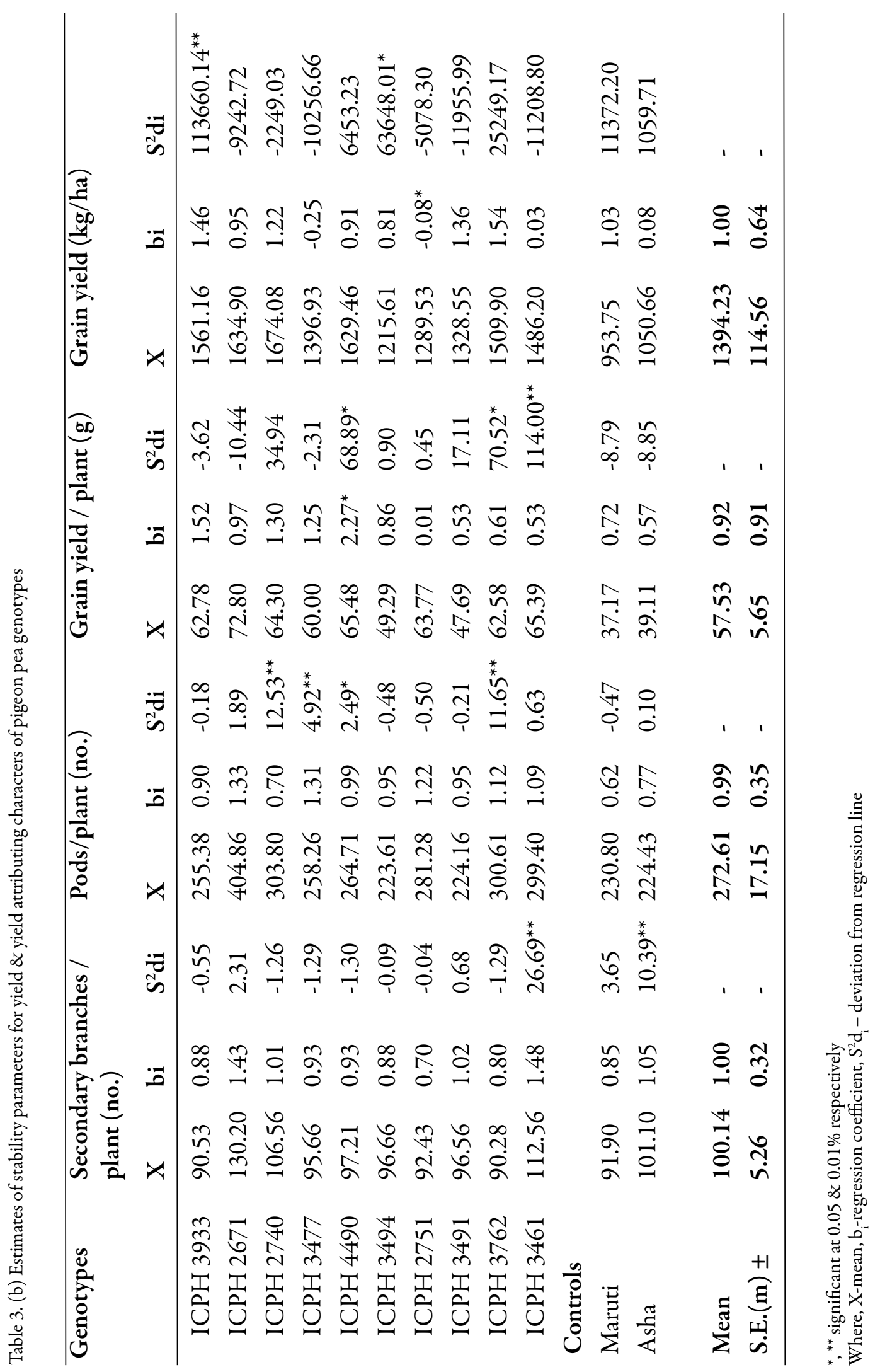




\section{Ranking biplot (Total - 89.63\%)}

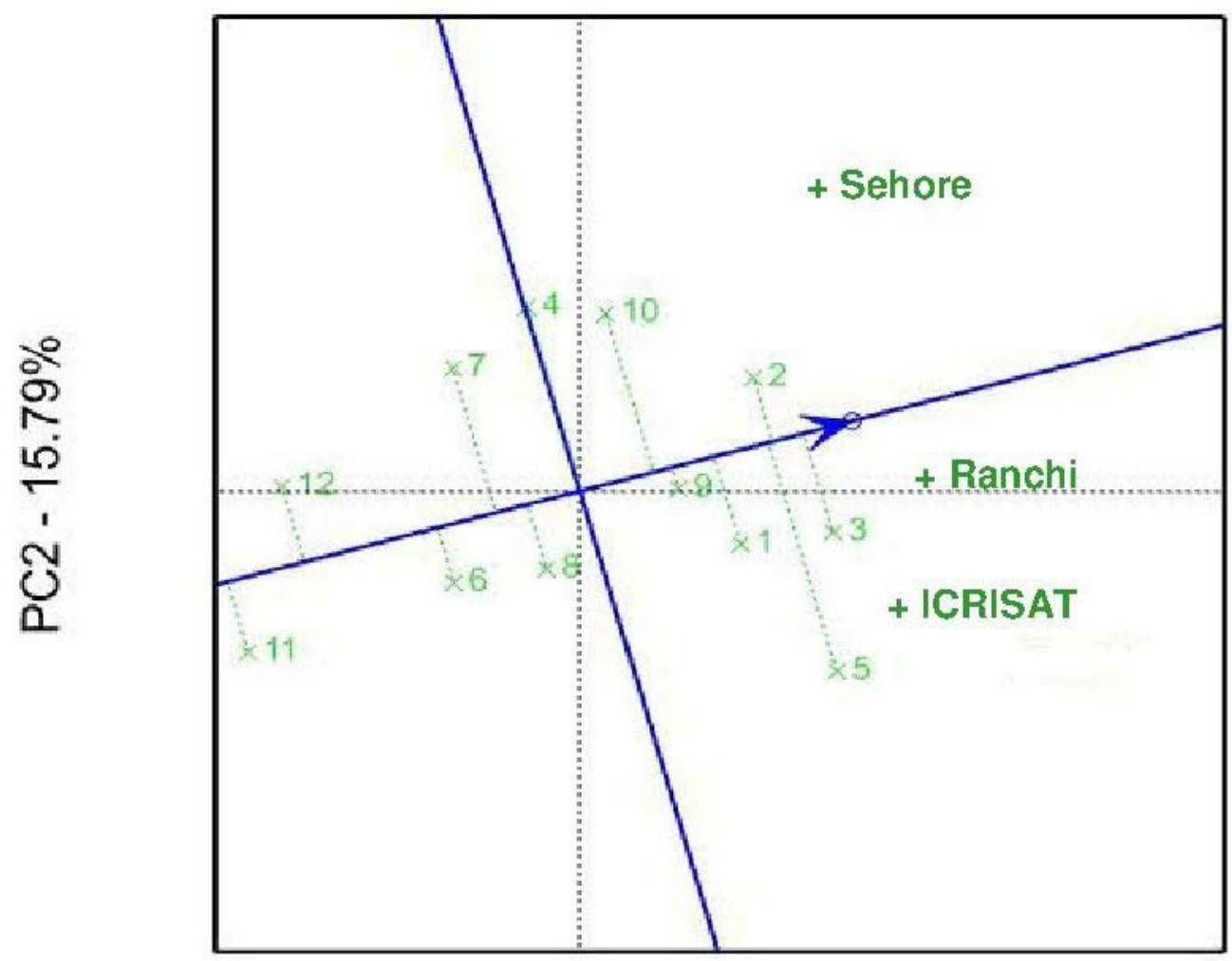

PC1 - $73.85 \%$

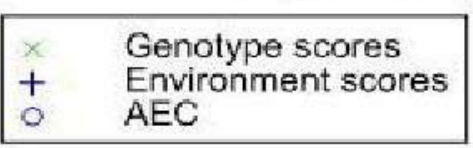

G1 (ICPH 3933), G2 (ICPH 2671), G3 (ICPH 2740), G4 (ICPH 3477), G5 (ICPH 4490), G6 (ICPH 3494), G7 (ICPH 2751), G8 (ICPH 3491), G9 (ICPH 3762), G 10 (ICPH 3461), G11 (Maruti), G12 (Asha)

Figure 1. Ranking GGE biplot of stability and mean performance of grain yield ( $\mathrm{kg} / \mathrm{ha})$ of pigeon pea genotypes in three environments

3933) and G9 (ICPH 3762) as stable hybrids in three diverse locations. Discriminating power and representativeness view of the GGE biplot is an important measure of testing environment (Dehghani et al.2006). A test environment that has a smaller angle with the AEA (average environment axis) is more representative environments of other test environments (Yan \& Tinker 2006). Thus, Ranchi was the most representative environments, whereas Patancheru and Sehore with the large deviation from AEA were the desirable locations for the testing of the hybrid trials.

\section{Ranking Genotypes Relative to the Ideal Genotype}

An ideal genotype should have the highest mean performance and be absolutely stable. Such an ideal genotype is defined by having the greatest vector length of the high yielding genotypes and with zero $\mathrm{G} \times \mathrm{E}$ interaction, as represented by an arrow pointing to it (Fig. 1). An ideal genotype is one with a large PC1 score represents the high yielding ability and small PC2 score represents high stability (Yan et al., 2000). Figure 1 reveals that G2 (ICPH 2671) and G3 (ICPH 2740), which fell 
into the center of concentric circles, were ideal genotypes in terms of high yielding ability and stability, compared with the rest of the genotypes. In addition, G10 (ICPH 3461), G5 (ICPH 4490) and G9 (ICPH 3762), located on the next concentric circle, may be regarded as desirable genotypes. Thus, G2 (ICPH 2671), G3 (ICPH 2740), G5 (ICPH 4490) and G10 (ICPH 3461) had the highest mean yield. Thus, G12 (Asha) was highly unstable whereas G9 (ICPH 3762) was highly stable, followed by G2 (ICPH 2671), G3 (ICPH 2740), G5 (ICPH 4490) and G10 (ICPH 3491) for grain yield/ plant. Similar findings were reported by Sawargaonkar et al. (2011), Kyu et al. (2011) and Srivastava et al. (2012) by using GGE biplot method for grain yield/plant in pigeon pea. Yield performance and stability of genotypes were evaluated by an average environment coordination (AEC) method. The single-arrowed line is the AEC abscissa, it points to higher mean yield across environments (Yan \& Tinker 2006). Based on the above information, ICPH 2671 (G2), ICPH 2740 (G3), ICPH 3933 (G1) and ICPH 3762 (G9), which had above average mean performance and were fairly stable were the most desirable of all the genotypes. G5 (ICPH 4490) was screened highest yielding hybrid in ICRISAT location, but unstable for other two locations. The present study showed that Ranchi is the closest to the ideal environment, while ICRISAT and Sehore are the most desirable environments. The GGE biplot explains higher proportions of the sum of squares of the $\mathrm{G} \times \mathrm{E}$ interaction and is more informative with regards to environments and cultivar performance than the Eberhart and Russell model.

\section{Conclusions}

In conclusion, the results of this study indicated that pigeon pea hybrids grain yield performance were highly influenced by environmental effect followed by the magnitude of genotype $x$ environment interaction and genotypes contributed the least effect. Hybrid ICPH 2671 expressed stable performance for grain yield and other characters in three diverse environments studied by Eberhart \& Russell model (1966) and GGE biplot model (Yan et al. 2000). Other hybrids ICPH 2740, ICPH 2751 and ICPH 3762 which had above average mean performance and were fairly stable of most of the genotypes were the most desirable.

\section{References}

Dalvi, V.A., Saxena, K.B, Luo, R.H. \& Li, Y.R. (2010). An overview of male-sterility systems in pigeon pea [Cajanus cajan (L.) Millsp.]. Euphytica, 173:397-407.

Dalvi, V.A., Saxena, K.B. \& Madrap, I.A.(2008). Fertility Restoration in Cytoplasmic- Nuclear Male-Sterile Lines Derived from 3 Wild Relatives of Pigeon pea. J. Hered., 99:671-673.

Dehghani, H., Ebadi, A. \& Yousefi, A. (2006). Biplot analysis of genotype by environment interaction for barley yield in Iran. Agron. J., 98:388-393.

Eberhart, S.A. \& Russell, W.A. (1966). Stability parameters for comparing varieties. Crop Sci., 6: 36-40.

FAO (2012). Database, retrieved from www.faostat.org

Gabriel, K.R. (1971). The biplot-graphical display of matrices with an application to principal component analysis. Biometrica, 58:453-467.

Gauch, H.G. \& Zobel, R.W. (1996). AMMI analysis of yield trials. In: Genotype by environment interaction. Eds. Kang \& Gauch. CRC Press, Boca Raton, New York.

Ghodke, M.K., Jahagirdar, J.E. \& Makne, V.G. (1992). Phenotypic stability of newly developed pigeon pea genotypes. Ind. J. Pulses Res., 5: 125-127.

Kalaimagal, T. \& Ravikesavan, R. (2003). Desirability index - a simple analysis for selection of stable genotypes in pigeon pea (Cajanus cajan (L.) Millsp.). Plant Arch., 3:121-123.

Kyu, K.L., Saxena, K.B., Kumar, R.V. \& Rathore, A. (2011). Prospects of hybrids in enhancing production and productivity of pigeon pea in Myanmar. J. Food Leg., 24: 1-7.

Manivel, P., Rangasamy, P. \& Samdur, M.Y. (1998). Phenotypic stability of hybrids and their parents for seed yield in pigeon pea (Cajanus cajan (L.) Millsp.). Crops Res., 15:108-111.

Mula, M., Saxena, K.B., Kumar, R.V. \& Rathore, A. (2010). Effect of spacing and irrigation on seed production of CMS-based pigeon pea hybrid. Green Farm., 1: 221-227.

Phad, D.S., Madrap, I.A. \& Dalvi, V.A. (2005). Studies on genotype $\times$ environment interaction and stability in pigeon pea. Indian J. Pulses Res., 18 : 156-157.

Saxena, K.B. \& Sharma, D. (1990). Pigeon pea genetics. In: The Pigeon pea, (Nene, Y.L., Hall, S.D. and Sheila, V.K. eds) CAB International, Wallingford, U.K., pp 137 - 158.

Saxena, K.B., Kumar, R.V., Srivastava, N. \& Shiying, B. (2005). A cytoplasmic-genic male-sterility system derived from a cross between Cajanus cajanifolius and Cajanus cajan. Euphytica, 145: 291-296.

Saxena, K.B., Sultana, R., Mallikarjuna, N., Saxena, R.K., Kumar, 
R.V., Sawargaonkar, S.L., \& Varshney, R.K. (2010). Male-sterility systems in pigeon pea and their role in enhancing yield. Plant Breeding. 129:125-134.

Saxena, K.B., Sultana, R., Saxena, R.K., Kumar, R.V., Sandhu, J.S., Rathore, A., Kishor, P.B.K. \& Varshney, R.K. (2011). Genetics of Fertility Restoration in A4-Based, Diverse Maturing Hybrids of Pigeon pea [Cajanus cajan (L.) Millsp.]. Crop Sci., 51:1-5.

Sawargaonkar, S.L., Madrap, I.A., Saxena, K.B. \& Rathore, A. (2011). Stability analysis of yield and related traits in pigeon pea hybrids. J. Food Leg., 24-3:184-193.

Srivastava, R.K., Rathore, A., Vales, M.I., Kumar, R.V., Panwar, S. \& Thanki, H.P. (2012). GGE biplot based assessment of yield stability, adaptability and mega-environment characterization for hybrid pigeon pea (Cajanus cajan). Ind. J. Agil. Sci., 82 -11 .
Thanki, H.P., Pithia, M.S. \& Mehta, D.R. (2007). Stability analysis for seed yield and its components in pigeon pea [Cajanus cajan (L.) Millsp.]. National J. Plant Impro., 9:103-105.

Wanjari, K.B., Patil, A.N., Fulzele, G.R. \& Ghavghave, P.B. (1988). A note on stability analysis in pigeon pea (Cajanus cajan (L.) Millsp.). Ann. Plant Physiol., 2: 113-114.

Yan, W., Hunt, L.A., Sheng, Q. \& Szlavnics, Z. (2000). Cultivar evaluation and mega-environment investigation based on the GGE biplot. Crop Sci., 40: 597-605.

Yan, W. \& Kang, M.S. (2002). GGE biplot analysis: A graphical tool for Genetists, Breeders and Agronomists.CRC Press, Boca Raton, FL.271.

Yan, W. \& Tinker, N.A. (2006). Biplot analysis of multi-environment trial data; Principles and applications. Can. J. Plant Sci., 86:623-645.

\title{
Stabilnost prinosa hibrida kajana (golubijeg graška) [Cajanus cajan (L.) Millsp.] u različitim agroekoloskim regionima
}

\author{
Uttam Chand • Ashok Narayan Tikle • Niraj Kumar • \\ Kul Bhushan Saxena • Sunil Chaudhari
}

\begin{abstract}
Sažetak: Dvanaest genotipova kajana (golubijeg graška) koji se sastoje od deset hibrida i dve kontrole su testirani u tri sredine tokom kišne sezone 2012-2013. u cilju ispitivanja interakcije genotip $\times$ sredina za prinos i komponente prinosa. Analiza varijanse u svakoj sredini ispoljila je značajne razlike među genotipovima za prinos $i$ komponentama prinosa, osim za masu 100 zrna. Linearne interakcije genotip $\times$ sredina su bile značajne za broj dana do $50 \%$ cvetanja, visinu biljke, broj primarnih i sekundarnih grana po biljci, broj mahuna po biljci, broj semena u mahuni, prinos zrna po biljci i prinos (kg/ha) osim broja dana do zrelosti i masu 100 zrna. Metode regresije i GGE biplot su korišćene za analizu. Obe metode su identifikovale ICPH 2671, ICPH 2740, ICPH 3933 i ICPH 3762 kao stabilne hibride. GGE biplot je objasnio veću proporciju srednje sume kvadrata interakcije $\mathrm{G} \times \mathrm{E}$ i bilo je informativniji u smislu sredina i njihovih genotipskih performansi od metode regresije. Hibridi ICPH 2671, ICPH 2740, ICPH 3762 i ICPH 3933 su pokazali stabilnost za prinos i komponente prinosa i mogu se preporučiti za gajenje. Ključne reči: Cajanus cajan, GGE biplot, hibridi, interakcija GxE, kajan (golubiji grašak), stabilnost prinosa
\end{abstract}

